\section{Mobile Learning Usage and Preferences of Vocational Secondary School Students: The cases of Austria, the Czech Republic, and Germany}

\author{
Antun Biloš \\ Faculty of Economics in Osijek, Josip Juraj Strossmayer University of Osijek, \\ Croatia \\ abilos@efos.hr \\ Davorin Turkalj \\ Faculty of Economics in Osijek, Josip Juraj Strossmayer University of Osijek, \\ Croatia \\ davorin@efos.hr

\section{Ivan Kelić} \\ Faculty of Economics in Osijek, Josip Juraj Strossmayer University of Osijek, \\ Croatia \\ ikelic@efos.hr
}

\begin{abstract}
The purpose of this paper is to determine the current status of mobile device usage and mobile learning adoption in vocational education and training (VET) secondary schools in three European Union countries (Austria, the Czech Republic, and Germany). The research focused on exploring students' mobile device usage habits, their attitudes toward education in the context of mobile application support, and preferences regarding mobile learning features. The research confirmed a high level of mobile device usage among secondary school students on a daily basis; smartphones and laptops were the most commonly used devices. The vast majority of participants perceived themselves to be advanced mobile device users, but reported a deficit of ICT-assisted mobile learning experience. However, the majority of respondents with prior ICT-assisted education experience described it as a positive or very positive experience. In addition, study participants tended to agree that mobile learning will play a significant role in education in the future. The paper also explored the reported differences among the students in the three countries and suggested several implications for understanding students' views of mobile learning. The findings provide insights into possibilities of m-learning implementation while creating a framework for $\mathrm{m}$-learning application development in the VET secondary school environment.
\end{abstract}

Key words: mobile learning, secondary school education, online teaching, student mobile device usage, m-learning, mobile teaching
ORIGINAL SCIENTIFIC PAPER

RECEIVED: SEPTEMBER 2016

REVISED: JANUARY 2017

ACCEPTED: JANUARY 2017

DOI: 10.1515/ngoe-2017-0006

UDK: 37:004.5/.7

JEL: D83

Citation: Biloš, A., Turkalj, D., \& Kelić, I. (2017). Mobile Learning Usage and Preferences of Vocational Secondary School Students: The cases of Austria, the Czech Republic, and Germany. Naše gospodarstvo/Our Economy, 63(1), 59-69. DOI: 10.1515/ngoe-2017-0006

\section{NG OE}

NAŠE GOSPODARSTVO OUR ECONOMY

\section{Vol.63: No.1:2017}

pp. $59-69$ 


\section{Introduction}

The global Internet and mobile development of the $21^{\text {st }}$ century are persistently reshaping the social existence by fundamentally affecting the various levels of communication, socialization, and information exchange. Information access and usage have been significantly influenced by the adoption of mobile devices such as portable computers (laptops), mobile phones, tablets, wearables, and similar devices. Such change is affecting the entire user experience across various screens, devices, and channels (Adams, Burkholder, \& Hamilton, 2015). Mobile devices are highly individualized communication tools (Bacile, Ye, \& Swilley, 2014) that have made global access to digital information possible while enabling its users to initiate engagement with desired content at the time and place of their preference (Fulgoni, 2016). Furthermore, the learning landscape is being transformed by the emerging influence of digital communication and omnipresent network-based applications, rapid advancement in mobile technologies and features ( $\mathrm{Wu}$ et al., 2012), and growing availability of various mobile applications (or apps, for short) (Hsu, Rice, \& Dawley, 2012). The growing changes in mobile technologies are followed by the changing characteristics, needs, and demands of the end-users, including various young target audiences, such as students (McLoughlin \& Lee, 2010).

Education systems are heavily influenced by these changes as well. The labor market's increasing knowledge and skills requirements in the modern economy have created various challenges for education systems. These systems operate in constant conflict with the harmonization of curriculum and learning methods created to ensure competitiveness and professional development of its users. The education process is experiencing reforms on all levels to determine both general and specific competences as a result of a dialog between education systems' stakeholders and employers. The potential end result of these combined efforts is an increased mobility and competitiveness within the labor market together with the promotion of lifelong learning as an essential part of participation in the modern, digitally enhanced economy. The initiatives for overcoming these challenges have been created in various European Union programs and international organizations, like UNESCO, which emphasize the strategic importance of mobile technology adoption in education systems' modern learning process. Mobile technology clearly empowers a "here-andnow" type of learning, providing "anytime and anywhere access to information, processes, and communication" (Martin \& Ertzberger, 2013, p. 76).

Mobile devices enhanced with social media and wireless connectivity are enabling highly personalized learning opportunities for both students and educators. Moreover, constantly connected mobile devices create opportunities for interaction and collaboration while enabling students to engage in content creation and communication using social media and Web 2.0 tools (Gikas \& Grant, 2013). Internet-based and mobile technologies can significantly reduce dependence on fixed locations for work-related activities and education, thereby providing the obvious potential to equally empower the business-oriented and educational processes (Peters, 2007). In addition, the incorporation of student-owned devices within the classroom is becoming an efficient and effective solution for many schools and universities alike (Blackboard, 2012).

Cheon, Lee, Crooks, and Song (2012) argued that the emerging technologies could resolve the technical limitations of mobile devices, such as lower resolution, network speed, and platform comparability, and much improvement has been made in this area over the last few years. Mobile technologies have started to make significant contributions to mobile teaching and mobile learning by providing personalized and customized contextual learning experiences (Brown \& Mbati, 2015). With broader implementation on different levels, technology will most likely continue to prove its usefulness in engaging students and empowering education, thereby becoming an invaluable improvement to the classroom experience (McQuiggan, McQuiggan, Sabourin \& Kosturko, 2015). Furthermore, the same authors concluded that Internet and mobile technologies offer great opportunities to drastically change education and learning, but only if knowledgeable, creative, and open-minded educators, teachers, and administrators embrace them.

The purpose of this paper is to determine the current status of mobile device usage and mobile learning adoption in vocational education and training (VET) secondary schools based on samples from three European Union countries (i.e., Austria, the Czech Republic, and Germany). The research focused on exploring students' mobile device usage habits, attitudes toward education in the context of mobile application support, and preferences regarding mobile learning features. For the purpose of this research, several research questions were formulated: How often do students go online? Which types of mobile device do students own and use? Which device is considered their primary mobile device? When and how frequently does mobile device usage occur? How do students perceive themselves as mobile device users? Do students have any previous ICT-assisted education experience? How do students perceive their former ICT-assisted education experience? What are the benefits and barriers of mobile learning from the students' point of view? What are students' preferences regarding the types and features of mobile learning software? Are there any significant differences among respondents in the selected countries? 


\section{Mobile Learning (m-learning)}

With the worldwide popularization of mobile devices over the last decade, interest in the educational use of mobile technologies and mobile devices has been increasing. Various mobile devices provide educational opportunities for students to access course content and interact with both lecturers and student colleagues regardless of their physical location (Cavus \& Ibrahim, 2009; Gikas \& Grant, 2013; Kukulska-Hulme \& Shield, 2008; Richardson \& Lenarcic, 2008). The constant change and significant productivity in mobile learning research are characterized by development in mobile technology culture (Hsu \& Ching, 2015; Rushby, 2012; Taylor, 2011; Wu et al., 2012). These technological developments have motivated both educators and researchers alike to take a pedagogical view on developing educational applications for various types of mobile devices in order to promote teaching and learning (Kearney, Schuck, Burden, \& Aubusson, 2012; Wu et al., 2012). Integrating technology into the education process is an essential method of engaging and interacting with students of the $21^{\text {st }}$ century.

Many definitions of mobile learning (or m-learning in short) have been put forth, but many authors agree on the core concept (Amara, Macedo, Bendella \& Santos, 2015; Barreh \& Abas, 2015; Chu, Hwang \& Tsai, 2010; Hwang \& Chang, 2011; Sharples, Corlett, \& Westmancott, 2002; Valk, Rashid, \& Elder, 2010): M-learning is a specific learning environment that takes advantage of mobile technologies through handheld devices and wireless networks. M-learning can be perceived as an independent part of e-learning (Park, Nam \& Cha, 2012). Other researchers have focused more on learners and learning experiences, but the main principles generally remain the same (Barreh \& Abas, 2015). However, Gikas and Grant (2013) suggested that m-learning is more than just learning supported by mobile devices; it is a specific learning type that is formal and informal, context-aware, and authentic for the learner. Wong (2012, p. E19) focused on the seamless component of m-learning where a learner can learn in a "variety of scenarios and in which they can switch from one scenario or context to another easily and quickly, with the personal device as a mediator.”

M-learning provides numerous benefits from both an educational and technological point of view. The learning process can be personalized and ubiquitous, yet spontaneous and informal (Miangah \& Nezarat, 2012) as well as practical and cost-saving (Cheon et al., 2012). Mobile technologies enable students and educators to share information easily, communicate, and coordinate projects (Snell \& Snell-Siddle, 2013). Furthermore, m-learning empowers the shift from teacher-led learning to student-led learning (Boticki, Baksa, Seow \& Looi, 2015; Land \& Zimmerman, 2015; Miangah \& Nezarat, 2012), thereby resulting in students willingly using the technology more effectively. Based on the features of m-learning, four types of approaches can be supported by mobile technologies: individualized learning, situated learning, collaborative learning, and informal learning (Cheon et al., 2012). M-learning supports individualized learning by allowing students to learn at their own pace while the situated component embodies the use of mobile devices to learn within a realistic context. Collaborative learning is accomplished when students use mobile devices to easily interact and communicate with other students. Finally, informal learning supports students in learning outside of the classroom at their own convenience (Jones, Scanlon \& Clough, 2013). In addition, Peters (2007, p. 1) suggested that m-learning enables the new methods of delivery that are highly suited to the "just enough, just in time, and just for me” demands of modern education environments.

The traditional learning process can be enriched and developed through the usage of mobile devices. Miangah and Nezarat (2012) argued that m-learning is not a substitute for existing learning devices, but an extension for learning in the new environment with new and improved capabilities. Successful personalized educational applications are based on the principle that any software used within the learning process must provide the same level of functionality and usability for all students, regardless of their unique abilities (Grant \& Basye, 2014). Furthermore, managing m-learning can allow educators to move from learning delivery to learning management and simultaneously help learners acquire specific skills of immediate value in the knowledge-based economy (Peters, 2007).

One could argue that m-learning adoption is slowly becoming a worldwide accepted practice (Hwang \& Wu, 2014). Osaka Jogakuin College in Japan became the first educational institution to provide m-learning devices (tablets) to its students to assist in learning a foreign language (McCarty, 2005). It was soon followed by several similar initiatives worldwide (Hsu, Hwang \& Chang, 2013; Lim, Fadzil \& Mansor, 2011). Peters (2007) suggested that mobile technologies were in common use in different commercial sectors, but their use exclusively for learning was relatively rare. Several papers have addressed students' attitude toward mobile device usage and their experience with m-learning. In his research, Taylor (2011) concluded that students themselves did not articulate any educational possibilities for mobile technologies. However, more recent articles have found that teenagers/students possessed positive attitudes toward the use of mobile devices for gaming, entertainment, and learning purposes (Kee \& Samsudin, 2014; Snell \& Snell-Siddle, 2013), although they had little experience in using mobile devices for learning-related activities (Kee \& Samsudin, 2014). Researchers have emphasized the need for well-designed learning support of m-learning in order to improve 
students' learning achievements (Hwang \& Chang, 2011). More specifically, a recent study suggested that mobile notifications and learning analytics could be used to foster self-regulated learning (Tabuenca, Kalz, Drachsler \& Specht, 2015).

Students at online universities have started to accept mobile technology as a rather new learning tool while the acceptance of mobile devices has influenced their learning achievement both directly and indirectly (Shin \& Kang, 2015). However, according to Barreh and Abas (2015), m-learning in the higher education environment has not become widespread as it is still in the testing stage. Moreover, the research into m-learning has mainly been based on the challenges and opportunities of this technology in education in general and in online distance learning in particular. A research paper by Leinonen, Keune, Veermans, and Toikkanen (2014) indicated the potential for fostering the practice of reflection in classroom learning through the use of mobile apps for audio and visual recordings. In addition, the use of mobile technologies and multimedia increases the interest of students with special educational needs, helping them learn while entertaining them (Fernández-López, Rodríguez-Fórtiz, Rodríguez-Almendros, \& Martínez-Segura, 2013). Clearly, there are many initiatives for using m-learning approaches for educational purposes, but the available academic and professional research on this topic is still rather limited, thereby providing an unexplored area for further research activities.

\section{Methodology and Research}

This research focused on exploring students' mobile device usage habits, their attitudes toward education in the context of mobile application support, and preferences with regard to mobile learning application features in vocational education and training secondary schools in three European countries as a part of Erasmus+ Mobile Application for Skills Training in EntRepreneurShip (MASTERS) project. Entrepreneurial education and training has been identified as one of the highest priorities by the European Commission within the Europe 2020 strategy (European Commission, 2010). These skills are even more important in the field of VET as it adds an essential qualification to young people's careers. Its main objective is to increase the labor market relevance of VET, promote entrepreneurship education and social entrepreneurship among young people, and enhance digital integration in learning, teaching, training, and youth work at various levels. As a result of this entrepreneurial demand, the Austrian Chamber of Commerce developed a specific program, the Entrepreneurs Skills Certificate (ESC), which was successfully implemented in Austria and transferred to the Czech Republic, Germany, and other European countries.

For the purpose of this research, several research questions were formulated:

- How often do students go online?

- Which types of mobile device do students own and use?

- Which device is considered a primary mobile device?

- When and how frequently does mobile device usage occur?

- How do students perceive themselves as mobile device users?

- Do students have any previous ICT-assisted education experience?

- How do students perceive their former ICT-assisted education experience?

- What are the benefits and barriers of mobile learning from the students' point of view?

- What are students' preferences regarding the types and features of mobile learning software?

- Are there any significant differences among respondents in the selected countries?

The online questionnaire consisted of 25 items divided into 4 sections: introductory welcome page, demography, mobile device usage, and user preferences toward m-learning. The questionnaire mostly consisted of closed-ended questions and several user approximations based on participants' experiences. The questionnaire was originally created in English and translated and revised in German and Czech languages by professional translators. A pilot study was created and conducted with project partners from the three selected countries prior to data collection in order to test the research instrument and avoid any impeding errors or confusion in the questionnaire. Several minor changes and refinements were implemented after the pilot study.

The research data was collected using SurveyGizmo software during January and February 2016 in VET secondary schools in Austria, the Czech Republic, and Germany. The secondary schools that implemented this entrepreneurial education program were able to participate in this research. A purposive sample was used as predefined by the project's proposition. Data were collected during classes in computer labs and supervised by the lecturers in order to ensure adequate introduction to the questionnaire and quality of the collected data. Ultimately, 383 respondents completed an online survey; 346 were valid and analyzed while the remaining 37 were disqualified due to partial responses and otherwise unusable data. The respondents come from three countries-41.3\% from the Czech Republic, 31.5\% from Austria, and 27.2\% from Germany-and were secondary school students aged 14 to 21 , with an average respondent age of 17.24 years. Of the 346 respondents, $83.8 \%$ were 
male and $16.2 \%$ were female, which can be attributed to the fact that the selected target group is made up of students of secondary vocational schools for professions usually characterized as male-dominant. Descriptive statistics, ANOVA and chi-square tests were used to analyze the results of an online survey.

\section{Research Results}

Survey respondents go online very often regardless of the used device: More than $45 \%$ of the students reported using the Internet almost constantly and an additional $45 \%$ reported going online several times a day. Consequently, the majority (90.8\%) of respondents can be categorized as extensive Internet users. Only $2 \%$ of respondents reported using the Internet less than once a week. Almost every respondent (98\%) owned at least one type of a mobile device (any type of smartphone, non-smartphone mobile device, tablet, phablet, or laptop computer). Smartphones and laptops were the most commonly used devices, at $93.9 \%$ and $73.7 \%$, respectively, while $41 \%$ of the respondents owned a tablet. Interestingly enough, respondent user groups of a particular device spent on average more than 5.5 hours a day (with a mean score $(\mathrm{M})$ of $\mathrm{M}=5.68$ and a standard deviation (SD) of SD = 5.14) using a smartphone, almost 4 hours $(\mathrm{M}=3.91$, $\mathrm{SD}=3.27)$ using a laptop, and 2.5 hours using a tablet $(\mathrm{M}=2.44$, $\mathrm{SD}=3.7)$. More than $90 \%$ of respondents reported using their mobile devices several times a day or more. In addition, almost three quarters $(74.2 \%)$ of respondents attributed their smartphone as their single primary mobile device while $18.5 \%$ said the same for their portable computers or laptops. Furthermore, using an elaborated 4-level experience scale (novice, intermediate, advanced, and expert), almost 68\% of respondents described themselves as advanced mobile device users, and more than $6 \%$ perceived themselves as expert mobile device users (Table 1). It should be mentioned that there could be a difference between perceived user type (measured as a self-reporting item) and actual mobile device experience. However, category descriptions were provided to describe and clarify the differences between the categories:

- $\quad$ Novice: I have been using a mobile device for less than 6 months and have only a few apps installed. I use my mobile device for calls, texting, and e-mail.

- Intermediate: I have been using a mobile device for more than 6 months. I occasionally download apps when I have a need or when my friends recommend something new.

- Advanced: I have been using a mobile device for 2+ years and have installed and used a variety of different apps. I often install many of the same types of apps to evaluate differences and make recommendations to my friends about the best ones.

- $\quad$ Expert: I have developed my own mobile apps.

Table 1. Mobile Device User Distribution by Perceived User Type

\begin{tabular}{lll} 
Mobile device user category & Frequency & Percent \\
\hline Novice & 8 & $2.3 \%$ \\
\hline Intermediate & 80 & $23.1 \%$ \\
\hline Advanced & 235 & $67.9 \%$ \\
\hline Expert & 23 & $6.6 \%$ \\
\hline Total & 346 & $100.0 \%$ \\
\hline
\end{tabular}

Source: Authors' research

Based on reported data, slightly more than one third (33.8\%) of the respondents reported having prior experience with some type of ICT-assisted education before. However, the vast majority (76.1\%) of the respondents with prior ICT-assisted education experience described it as positive or very positive (measured on a 5-point Likert scale). In addition, $62.4 \%$ of all respondents agreed or strongly agreed that mobile learning would play a significant role in education in the future (measured on a 5-point Likert scale).

Most respondents agreed on several benefits of m-learning: easier access to coursework (68.5\%), increased knowledge in the field of study (62.7\%), and increased communication with other students (50.3\%). In contrast, when rating barriers to the use of m-learning, respondents tended to be somewhat neutral (respondents mostly answered with a neutral mid-point on a given 5-point scale). This could be attributed to the fact that they did not have extensive previous experience with ICT-assisted instruction. The respondents also suggested that the most important factors for the usage of m-learning applications were progress report/notifications ( $\mathrm{M}=3.7, \mathrm{SD}=1.06$; based on a 5-point Likert scale) followed by app usage of friends or colleagues $(\mathrm{M}=3.33, \mathrm{SD}=1.03)$ and unlocking new in-app content $(\mathrm{M}=3.32, \mathrm{SD}=1.08)$ (see Table 2$)$.

Respondents were asked to express their preference regarding the features of a potential m-learning application. The features with the highest-ranked scores were the ability to compare the results with colleagues (75.1\%), forum or chat (70.5\%), and social networking components (64.2\%). Furthermore, in terms of preferences regarding a single type of m-learning application, respondents scored game-based apps (27.2\%), tutorials (26.3\%), best practice/case studies (24\%), and quizzes (22.5\%) relatively equally. 
Table 2. Factors for Using M-learning Applications

\begin{tabular}{llllll} 
& $\mathrm{N}$ & Mean & & Std. Deviation & Variance \\
\cline { 2 - 6 } & Statistic & Statistic & Std. Error & Statistic & Statistic \\
\hline Incentives (stars) & 346 & 3.12 & .061 & 1.134 & 1.285 \\
\hline Exclusive/bonus content & 346 & 3.07 & .056 & 1.046 & 1.093 \\
\hline Progress report/notifications: & 346 & 3.70 & .057 & 1.061 & 1.126 \\
\hline Friends/colleagues start using the app & 346 & 3.33 & .055 & 1.031 & 1.062 \\
\hline Unlocking new in-app content & 346 & 3.32 & .058 & 1.083 & 1.173 \\
\hline Valid N (listwise) & 346 & & & & \\
\hline
\end{tabular}

Source: Authors' research

Table 3. Difference in Daily Smartphone and Laptop Usage among Students of 3 Observed Countries (ANOVA test)

\begin{tabular}{lllllll} 
& & Sum of Squares & df & Mean Square & F & Sig. \\
\hline \multirow{3}{*}{ Smartphone } & Between Groups & 222.899 & 2 & 111.449 & 4.308 & .014 \\
\cline { 2 - 7 } & Within Groups & 8278.542 & 320 & 25.870 & & \\
\cline { 2 - 7 } Portable computer/laptop & Total & 8501.441 & 322 & & 36.584 & .000 \\
\cline { 2 - 7 } & Between Groups & 593.841 & 2 & 296.920 & & \\
\cline { 2 - 7 } & Within Groups & 1809.889 & 223 & 8.116 & & \\
\cline { 2 - 7 } & Total & 2403.730 & 225 & & & \\
\hline
\end{tabular}

Source: Authors’ research

Several statistically significant differences can be observed when comparing respondents from the three studied countries. Although Internet usage is very high in general terms, Czech students tended to use the Internet the most (regardless of a particular device), with almost two thirds (64.3\%) reporting using the Internet almost constantly (48.9\% of German and $17.4 \%$ of Austrian respondents responded the same). In order to test the significance of the difference among the three countries, a chi-square test was used. The respondents were initially tested about their frequency of Internet usage using an elaborated 7-point scale of frequency. The variable was recoded into the new variable by condensing the scale to three frequency segments of Internet usage: once a day or less, several times a day, and almost constantly. The chi-square test confirmed the significance of the difference $(\chi 2=61.855$, $\mathrm{df}=4, p<0.01$ ), suggesting that there is enough evidence to conclude that respondents from three selected countries were not using the Internet at the same frequency.

In order to measure the significance of the observed differences in daily usage of a device, an ANOVA test was used (together with Levene's test for homogeneity of variances and post hoc tests). The ANOVA test showed significant differences in average daily smartphone usage and laptop usage among the respondent groups (see Table 3). German students reported the most daily smartphone usage, with almost 7 hours ( $M=6.96)$, compared to Czech students, who reported using their smartphones about 5 hours daily $(M=4.98)$. The
ANOVA test showed significant differences between the two groups ( $\mathrm{F}=4.308, \mathrm{df}=2, p=0.014)$. Levene's test showed that the assumption of homogeneity of variances was met, and the post hoc test (Bonferroni) confirmed the statistical significance of the mean difference between the two groups at the 0.05 level $(p=0.014)$. However, the same post hoc test (Bonferroni) did not show the statistical significance of the mean difference between the Austrian students and their German or Czech colleagues.

On the other hand, Czech students tended to use laptops the most, for an average of more than 5.5 hours a day, compared to fewer than 3 hours a day for both Austrian $(\mathrm{M}=2.86)$ and German $(M=2.13)$ students. The ANOVA test confirmed the significance of the difference $(\mathrm{F}=36.584, \mathrm{df}=2, p<0.01)$, but it should be noted that Levene's test suggested that the assumption of homogeneity of variances has been violated $(p<0.001)$. Therefore, additional tests of equalities of means were used. Both the Welch and Brown-Forsythe tests suggested that the tested groups were significantly different from each other ( $p<0.001$ for both). Furthermore, the post hoc test where equal variances were not assumed (Dunnett T3) confirmed the statistical significance of the mean difference between both Czech and German $(p<0.001)$ and Czech and Austrian $(p<0.001)$ students. As for the other devices used (non-smartphone, tablet, phablet), the ANOVA test did not show any significant differences among the three selected countries. 
Significant differences were also apparent in previous experience with any type of ICT-assisted education. Czech students were the most experienced ones, with almost half of the respondents reporting previous experience, while only $36 \%$ of German and $12 \%$ of Austrian students reported the same. The chi-square test confirmed the significance of the stated difference $(\chi 2=75.899, \mathrm{df}=4, p<0.01)$. In addition, Austrian students tended to be the least satisfied with their previous experience although the mean score suggested a neutral attitude $(\mathrm{M}=3.15, \mathrm{SD}=1.21$; based on a 5 -point Likert scale). The ANOVA test confirmed the significant difference between the level of satisfaction between Austrian students and others ( $\mathrm{F}=6.983, \mathrm{df}=2, p=0.001)$. Levene's test showed that the assumption of homogeneity of variances was met. The post hoc test (Bonferroni) confirmed the statistical significance of the mean difference between the Austrian and German students $(p=0.001)$ as well as the Austrian and Czech students $(p=0.004)$ at the 0.05 level. However, it should be taken into consideration that Austrian students had the least experience with any type of ICT-assisted education, which might have influenced their reported level of satisfaction. The same post hoc test (Bonferroni) did not show a statistical significance of the mean difference between the German and Czech students.

Although respondents generally agreed that m-learning would play a significant role in education in the future, German students showed a higher level of agreement $(\mathrm{M}=4.24, \mathrm{SD}=0.86$; based on a 5-point Likert scale) than both the Czech $(\mathrm{M}=3.53, \mathrm{SD}=1.01)$ and Austrian students $(\mathrm{M}=3.31, \mathrm{SD}=1.2)$. The ANOVA test confirmed the difference between the groups $(\mathrm{F}=22.086, \mathrm{df}=2, p<0.001)$, but Levene's test suggested that the assumption of homogeneity of variances was violated $(p=0.005)$. Consequently, both the Welch and Brown-Forsythe tests suggested that the tested groups were significantly different from each other ( $p<0.001$ for both). The post hoc test where equal variances are not assumed (Dunnett T3) confirmed the statistical significance of the mean difference between the German students and their Austrian $(p<0.001)$ and Czech counterparts $(p<0.001)$. However, the same post hoc test (Dunnett T3) did not show statistical significance of the mean difference between the Austrian students and their Czech colleagues.

Most respondents from the three observed countries agreed on several benefits of m-learning, although the Austrian students tended to express a more neutral view (scale neutral mid-point) on the benefits of m-learning. In addition, the German students rated the progress report/notification item among the most important factors for the usage of m-learning applications higher $(\mathrm{M}=4.12, \mathrm{SD}=0.91)$ than their Czech and Austrian colleagues alike $(\mathrm{M}=3.59, \mathrm{SD}=0.98$ and $\mathrm{M}=3.49$, $\mathrm{SD}=1.18$, respectively). The ANOVA test confirmed the significance of the difference $(\mathrm{F}=10.757, \mathrm{df}=$
2, $p<0.001$ ), but it should be noted that Levene's test suggested that the assumption of homogeneity of variances was violated. However, additional Welch and Brown-Forsythe tests ( $p<0.001$ for both) suggested that the tested groups were significantly different from each other. The post hoc test where equal variances were not assumed (Dunnett T3) confirmed the statistical significance of the mean difference between the German students and their Austrian $(p<0.001)$ and Czech counterparts $(p<0.001)$. However, the same post hoc test (Dunnett T3) did not show a statistical significance in the mean difference between the Austrian and Czech students.

In contrast to the total score, in terms of preferences regarding the type of m-learning applications, German students preferred tutorials (42.6\%), Czech students game-based apps (35\%), and their Austrian counterparts best practice/ case studies (30.3\%). A chi-square test was used to confirm the significance of the difference $(\chi 2=25.647$, df $=6$, $p<0.001)$.

\section{Conclusion, Limitations, and Further Research Guidelines}

The purpose of this paper was to determine the current status of mobile device usage and mobile learning adoption in VET secondary schools in three selected European countries: Austria, the Czech Republic, and Germany. The research focused on exploring students' mobile device usage habits and preferences, attitudes toward education in the context of m-learning, and preferences regarding mobile learning features.

Survey respondents go online very often regardless of the device used: More than $90 \%$ (90.8\%) of respondents could be categorized as extensive Internet users. The vast majority of respondents (98\%) owned at least one type of a mobile device, and more than $90 \%$ reported using their mobile devices several times a day or more often. Respondents indicated spending more than 5.5 hours a day on average using a smartphone, almost 4 hours using a laptop, and 2.5 hours using a tablet. In addition, almost three quarters (74.2\%) of respondents attributed their smartphone as their single primary mobile device while $18.5 \%$ said the same for their portable computers or laptops. Slightly less than three quarters $(74.5 \%)$ of respondents described themselves as advanced or expert mobile device users. Interestingly enough, only one third reported having previous experience with any type of ICT-assisted education. However, more than three quarters $(76.1 \%)$ of the respondents with prior ICT-assisted education experience described it as positive or very positive. Most respondents agreed on several benefits of 
m-learning: easier access to coursework (68.5\%), increased knowledge in the field of study (62.7\%), and increased communication with other students (50.3\%). In contrast, when rating barriers to the use of m-learning, respondents tended to be rather neutral. Respondents also suggested that the most important factors for the usage of m-learning applications were progress report/notifications followed by app usage of friends or colleagues and unlocking new in-app content.

Several significant differences can be observed when comparing respondents from the three studied countries. Although the Internet usage is high in general, Czech students tended to report using the Internet more frequently than their German and Austrian colleagues. German students led in daily smartphone usage, while the Czech students preferred laptops and reported themselves as being the most experienced group regarding previous ICT-assisted experience. Although respondents generally agreed that m-learning would play a significant role in education in the future, German students showed a significantly higher level of agreement. In contrast to the average reported score, in terms of preferences regarding the type of m-learning applications, German students preferred tutorials, Czech students mostly selected game-based apps, and their Austrian counterparts reported best practice/case studies. The findings provide insights into possibilities of m-learning implementation while creating a framework for m-learning app development in the VET secondary school environment. In addition, this paper provides theoretical and practical implications on m-learning adoption experience.

Finally, several observations and conclusions that can be interpreted in accordance with the main ideas of the literature review. Based on the provided research findings, the learning landscape of education systems is clearly being influenced and transformed by the emerging changes in digital and mobile communication possibilities. Mobile technologies have started to make compelling contributions to mobile learning within the VET secondary schools in the three observed European countries. Similar to several other papers, students stated mostly positive attitudes toward using mobile devices for various activities, including m-learning. However, the research participants had a similarly limited experience in using mobile devices for learning-related activities as reported in other research. This situation suggests a vast space for improvement of the classroom experience empowered with mobile technology used for m-teaching and m-learning alike.

This paper suffers from a number of limitations. Although the three selected countries provided an interesting perspective on the current status of mobile learning, a broader view on mobile device usage and the comprehension of m-learning could be achieved by including a larger number of countries and a broader scope of secondary school types. Furthermore, the self-reporting measurement is a clear limitation of the collected data and could affect several of the derived conclusions. Therefore, future research activities should consider a more objective measurement of mobile device usage and focus on a larger number of secondary schools and secondary school types as well as other target groups. In addition, future research efforts should focus on data comparison between different countries and time-related changes and trends. Finally, the available academic and professional research on this topic is still rather limited, thereby providing an unexplored area for further research activities.

\section{Funding Information}

This study is a part of Erasmus+ MASTERS project. The research is conducted with students covered through partner networks in the field of entrepreneurial education. MASTERS addresses several European as well as local objectives to enable young VET students for their future, improve economic situations, and foster educational development through ICTbased innovation. Given this entrepreneurial demand, the Austrian Chamber of Commerce developed a specific program: the Entrepreneurs Skills Certificate (ESC). This program was successfully implemented in Austria and transferred to the Czech Republic, Germany, and other European countries. Transferring unique know-how from one to another European country is the major reason for a transnational project.

\section{References}

Adams, L., Burkholder, E., \& Hamilton, K. (2015). Micro-moments: Your guide to winning the shift to mobile, think with Google. Retrieved from https://www.thinkwithgoogle.com/research-studies/micromoments-guide-pdfdownload.html

Amara, S., Macedo, J., Bendella, F., \& Santos, A. (2015). Dynamic group formation in mobile computer supported collaborative learning environment. In Proceedings of the 7th International Conference on Computer Supported Education CSEDU (p. 530-539). Lisbon: Institute for Systems and Technologies of Information, Control and Communication. https://doi.org/10.5220/0005438205300539 
Bacile, T. J., Ye, C., \& Swilley, E. (2014). From firm-controlled to consumer-contributed: Consumer co-production of personal media marketing communication. Journal of Interactive Marketing, 28(2) 117-133. https://doi.org/10.1016/j.intmar.2013.12.001

Barreh, K.A., \& Abas, Z. W. (2015). A framework for mobile learning for enhancing learning in higher education. Malaysian Online Journal of Educational Technology, 3(3), 1-9.

Blackboard. (2012). Learning in the 21st century. Mobile devices + social media = personalized learning. Project Tomorrow. Retrieved from http://www.blackboard.com/resources/markets/k-12/collateral/project-tomorrow/k12_prjct-tmrw_mbl-rpt_2012.pdf

Boticki, I., Baksa, J., Seow, P., \& Looi, C. K. (2015). Usage of a mobile social learning platform with virtual badges in a primary school. Computers \& Education, 86,120-136. https://doi.org/10.1016/j.compedu.2015.02.015

Brown, T. H., \& Mbati, L. S. (2015). Mobile learning: moving past the myths and embracing the opportunities. The International Review of Research in Open and Distributed Learning, 16(2). https://doi.org/10.19173/irrodl.v16i2.2071

Cavus, N., \& Ibrahim, D. (2009). m-Learning: An experiment in using SMS to support learning new English language words. British Journal of Educational Technology, 40(1), 78-91. https://doi.org/10.1111/j.1467-8535.2007.00801.x

Cheon, J., Lee, S., Crooks, S. M., \& Song, J. (2012). An investigation of mobile learning readiness in higher education based on the theory of planned behavior. Computers \& Education, 59(3), 1054-1064. https://doi.org/10.1016/j.compedu.2012.04.015

Chu, H. C., Hwang, G. J., \& Tsai, C. C. (2010). A knowledge engineering approach to developing mindtools for context-aware ubiquitous learning. Computers \& Education, 54(1), 289-297. https://doi.org/10.1016/j.compedu.2009.08.023

European Commission. (2010). Communication from the Commission Europe 2020 A strategy for smart, sustainable and inclusive growth. http://eur-lex.europa.eu/LexUriServ/LexUriServ.do?uri=COM:2010:2020:FIN:EN:PDF

Fernández-López, Á., Rodríguez-Fórtiz, M. J., Rodríguez-Almendros, M. L., \& Martínez-Segura, M. J. (2013). Mobile learning technology based on iOS devices to support students with special education needs. Computers \& Education, 61, 77-90. https://doi.org/10.1016/j. compedu.2012.09.014

Fulgoni, G. M. (2016). In the digital world, not everything that can be measured matters. Journal of Advertising Research, 56(3), 9-13. https://doi.org/10.2501/JAR-2016-008

Gikas, J., \& Grant, M. M. (2013). Mobile computing devices in higher education: Student perspectives on learning with cellphones, smartphones \& social media. The Internet and Higher Education, 19,18-26. https://doi.org/10.1016/j.iheduc.2013.06.002

Grant, P., \& Basye, D. (2014). Personalized learning: A guide for engaging students with technology. Eugene: International Society for Technology in Education.

Hsu, C. K., Hwang, G.J., \& Chang, C. K. (2013).A personalized recommendation-based mobile learning approach to improving the reading performance of EFL students. Computers \& Education, 63, 327-336. https://doi.org/10.1016/j.compedu.2012.12.004

Hsu, Y. C., \& Ching, Y. H. (2015). A review of models and frameworks for designing mobile learning experiences and environments. Canadian Journal of Learning and Technology, 41(3), 1-22. https://doi.org/10.21432/t2v616

Hsu, Y. C., Rice, K., \& Dawley, L. (2012). Empowering educators with Google's Android app inventor: An online workshop in mobile app design. British Journal of Educational Technology, 43(1), E1-E5. https://doi.org/10.1111/j.1467-8535.2011.01241.x

Hwang, G. J., \& Chang, H. F. (2011). A formative assessment-based mobile learning approach to improving the learning attitudes and achievements of students. Computers \& Education, 56(4), 1023-1031. https://doi.org/10.1016/j.compedu.2010.12.002

Hwang, G.J., \& Wu, P. H. (2014). Applications, impacts and trends of mobile technology-enhanced learning: a review of 2008-2012 publications in selected SSCI journals. International Journal of Mobile Learning and Organisation, 8(2), 83-95. https://doi.org/10.1504/ IJMLO.2014.062346

Jones, A. C., Scanlon, E., \& Clough, G. (2013). Mobile learning: Two case studies of supporting inquiry learning in informal and semiformal settings. Computers \& Education, 61, 21-32. https://doi.org/10.1016/j.compedu.2012.08.008

Kearney, M., Schuck, S., Burden, K., \& Aubusson, P. (2012). Viewing mobile learning from a pedagogical perspective. Research in Learning Technology, 20. https://doi.org/10.3402/rlt.v20i0.14406

Kee, C. N. L., \& Samsudin, Z. (2014). Mobile devices: Toys or learning tools for the 21st century teenagers?. Turkish Online Journal of Educational Technology-TOJET, 13(3), 107-122.

Kukulska-Hulme, A., \& Shield, L. (2008). An overview of mobile assisted language learning: From content delivery to supported collaboration and interaction. ReCALL, 20(3), 271-289. https://doi.org/10.1017/S0958344008000335

Land, S. M., \& Zimmerman, H.T.(2015). Socio-technical dimensions of an outdoor mobile learning environment: a three-phase design-based research investigation. Educational Technology Research and Development, 63(2), 229-255. https://doi.org/10.1007/s11423-015-9369-6

Leinonen, T., Keune, A., Veermans, M., \& Toikkanen, T. (2014). Mobile apps for reflection in learning: A design research in K-12 education. British Journal of Educational Technology, 47(1), 1-17.

Lim, T., Fadzil, M., \& Mansor, N. (2011). Mobile learning via SMS at Open University Malaysia: Equitable, effective, and sustainable. The International Review of Research in Open and Distributed Learning, 12(2), 122-137. https://doi.org/10.19173/irrodl.v12i2.926

Martin, F., \& Ertzberger, J. (2013). Here and now mobile learning: An experimental study on the use of mobile technology. Computers \& Education, 68, 76-85. https://doi.org/10.1016/j.compedu.2013.04.021

McCarty, S. (2005). Spoken Internet to go: Popularization through podcasting. JALT CALL, 1(2), 67-74.

McLoughlin, C., \& Lee, M.J. (2010). Personalised and self regulated learning in the Web 2.0 era: International exemplars of innovative pedagogy using social software. Australasian Journal of Educational Technology, 26(1), 28-43. https://doi.org/10.14742/ajet.1100

McQuiggan, S., McQuiggan, J., Sabourin, J., \& Kosturko, L. (2015). Mobile learning: A handbook for developers, educators, and learners. Hoboken: John Wiley \& Sons. https://doi.org/10.1002/9781118938942 
Miangah, T. M., \& Nezarat, A. (2012). Mobile-assisted language learning. International Journal of Distributed and Parallel Systems, $3(1), 309$. https://doi.org/10.5121/ijdps.2012.3126

Park, S. Y., Nam, M. W., \& Cha, S. B. (2012). University students' behavioral intention to use mobile learning: Evaluating the technology acceptance model. British Journal of Educational Technology, 43(4), 592-605. https://doi.org/10.1111/j.1467-8535.2011.01229.x

Peters, K. (2007). m-Learning: Positioning educators for a mobile, connected future. The International Review of Research in Open and Distributed Learning, 8(2). https://doi.org/10.19173/irrodl.v8i2.350

Richardson, J., \& Lenarcic, J. (2008). Text messaging as a catalyst for mobile student administration: the trigger experience. International Journal of Emerging Technologies and Society, 6(2), 140-155.

Rushby, N. (2012). Editorial: An agenda for mobile learning. British Journal of Educational Technology, 43(3), 355-356. https://doi. org/10.1111/j.1467-8535.2012.01313.x

Sharples, M., Corlett, D., \& Westmancott, O. (2002). The design and implementation of a mobile learning resource. Personal and Ubiquitous Computing, 6, 220-234. https://doi.org/10.1007/s007790200021

Shin, W. S., \& Kang, M. (2015). The use of a mobile learning management system at an online university and its effect on learning satisfaction and achievement. The International Review of Research in Open and Distributed Learning, 16(3). https://doi.org/10.19173/ irrodl.v16i3.1984

Snell, S., \& Snell-Siddle, C. (2013). Mobile learning: The effects of gender and age on perceptions of the use of mobile tools. In The Second International Conference on Informatics Engineering \& Information Science (pp. 274-281). Kuala Lumpur: The Society of Digital Information and Wireless Communication.

Tabuenca, B., Kalz, M., Drachsler, H., \& Specht, M. (2015). Time will tell: The role of mobile learning analytics in self-regulated learning. Computers \& Education, 89, 53-74. https://doi.org/10.1016/j.compedu.2015.08.004

Taylor, C. A. (2011). The mobile literacy practices of adolescents: an ethnographic study (Unpublished doctoral dissertation). Monash University, Faculty of Education, Victoria: Australia.

Valk, J. H., Rashid, A. T., \& Elder, L. (2010). Using mobile phones to improve educational outcomes: An analysis of evidence from Asia. The International Review of Research in Open and Distributed Learning, 11(1), 117-140. https://doi.org/10.19173/irrodl.v11i1.794

Wong, L. H. (2012). A learner-centric view of mobile seamless learning. British Journal of Educational Technology, 43(1), E19-E23. https:// doi.org/10.1111/j.1467-8535.2011.01245.x

Wu, W., Wu, Y. J., Chen, C., Kao, H., Lin, C., \& Huang, S. (2012). Review of trends from mobile learning studies: A meta-analysis. Computers \& Education, 59(2), 817-827. https://doi.org/10.1016/j.compedu.2012.03.016

\section{Authors}

Antun Biloš, Ph.D., is an assistant professor in the Department of Marketing, Faculty of Economics, J.J. Strossmayer University of Osijek, Croatia. His main research and lecturing interests include digital marketing, e-business, e-commerce, and marketing-information systems. He is the author or co-author of 20 scientific papers and 2 books and has participated in various domestic and international scientific and professional conferences. He has been a member of the Croatian Marketing Association (CROMAR) since 2007.

Davorin Turkalj, Ph.D., is an assistant professor at the Faculty of Economics in Osijek, Department of Marketing. His field of scientific and professional study includes digital marketing, multimedia marketing, management of services in a contemporary setting, and information and communication technologies in the service of agricultural marketing. As an author and co-author, he has published 25 scientific papers and 2 editions of e-marketing books. He also holds the position of vice director of the postgraduate program in marketing.

Ivan Kelić, Ph.D., has been employed by the Faculty of Economics in Osijek since 2011 as a teaching and research assistant in the Department of Marketing. Since 2011, he has participated in teaching different classes at the Faculty of Economics in Osijek (Marketing in Tourism, E-marketing, Mobile Marketing, Multimedia Marketing, and Management of Services). He has published 15 scientific papers in the field of implementing new technologies in contemporary business activities. 


\section{Uporaba mobilnega učenja in preference dijakov srednjega poklicnega izobraževanja: primeri Avstrije, Češke in Nemčije}

\section{Izvleček}

Namen članka je ugotoviti trenutno stanje pri uporabi mobilnih naprav in usvojitvi mobilnega učenja v srednjih šolah za poklicno izobraževanje in usposabljanje v treh državah Evropske unije, v Avstriji, Češki republiki in Nemčiji. Raziskava se osredotoča na navade dijakov pri uporabi mobilnih naprav, njihov odnos do izobraževanja v kontekstu podpore mobilnih aplikacij in na preference do značilnosti mobilnega učenja. Rezultati so potrdili, da dijaki vsak dan zelo veliko uporabljajo mobilne naprave, v splošnem največ pametne telefone in prenosne računalnike. Večina udeležencev se ima za napredne uporabnike mobilnih naprav, vendar govorijo tudi o pomanjkljivih izkušnjah z mobilnim učenjem, podprtim z IKT. Večina respondentov, ki že imajo izkušnje z učenjem, podprtim z IKT, je te izkušnje opisala kot pozitivne ali zelo pozitivne. Udeleženci se strinjajo, da bo imelo mobilno učenje v izobraževanju v prihodnosti pomembno vlogo. V prispevku raziskujemo tudi razlike med dijaki treh držav in predlagamo različne implikacije o razumevanju dijaških pogledov na mobilno učenje. Izsledki ponujajo vpogled v možnosti implementacije m-učenja s kreiranjem okvira za razvoj aplikacije m-učenja v srednjih šolah za poklicno izobraževanje in usposabljanje.

Ključne besede: mobilno učenje, srednješolsko izobraževanje, spletno poučevanje, uporaba mobilnih naprav pri dijakih, m-učenje, mobilno poučevanje 